\title{
SUCCESSION PLANNING AS A TOOL FOR ORGANIZATIONAL DEVELOPMENT: A CASE STUDY OF UNIVERSITY OF EDUCATION, WINNEBA - KUMASI, GHANA
}

\author{
ADWOA SERWAA KARIKARI* \\ University of Education, Winneba \\ College of Agriculture Education \\ Asante Mampong \\ RICHARD KODI \\ University of Education, Winneba \\ College of Agriculture Education \\ Asante Mampong \\ ROSEMARY ADU POKU \\ University of Education, Winneba \\ College of Agriculture Education \\ Asante Mampong \\ https://doi.org/10.37602/IJSSMR.2020.3412
}

\begin{abstract}
Recent years have seen the rise of human resource problems and concerns across global business circles. For most sectors and organisations, the lack of a strategy of succession planning is considered one of the main causes of problems that are reflected every day for workers' lives, affecting the degree of satisfaction they derive. The study specifically investigated the existence of succession planning, metric used in the selection of successors, succession planning policy functionalities and much more. The research employed a descriptive research design survey and a case study was considered for review by the University of Education, Winneba-Kumasi, Ghana. Quota sampling methodology was implemented in the collection of respondents. In the study of the data both qualitative and quantitative approaches have been adopted. The college has four faculties, a number of departments and units with a total membership of the staff population of 403 . The simple random sampling technique was used to obtain the sample size for the study. The selection was then done by random picking. In all, the study considered hundred (100) employees out of which twenty (20) represented views of senior management, forty (40) represented the view of senior staff members and forty (40) represent the views of junior staff members. The collected data were analysed using the Statistical Package for Social Science (SPSS) software. The study revealed that a succession plan program is in effect at the University of Education, Winneba - Kumasi, Ghana to fill key positions within the institution. This can be achieved by the University by training and development programs and job rotation. This has established that prospective applicants have been chosen through a screening, interview and performance evaluation process, in addition to considering certain personality characteristics
\end{abstract}




\section{International Journal of Social Sciences and Management Review}

of the applicants. Performance preparation at the university is primarily threatened by a lack of support for the organisation of training programs and the encouragement of staff. It is recommended that employees be adequately motivated to reap the full potential of succession planning.

Keywords: Succession Planning, Organisational Development, Employee Satisfaction, Employee Recruitment, Job Satisfaction

\subsection{INTRODUCTION}

The application of the mental faculties to the acquisition of knowledge of institutions and strategic behaviours is a novel science, and over the last 15 to 20 years, the themes of succession have only become popular due to high public and disastrous leadership transitions in successful companies. For those that are inexperienced, the potential for leadership disasters seems unavoidable. Rapid changes in strategies, business information-based jobs and processes and portfolio diversification from acquisitions and mergers challenge corporate executives' ability to lead their companies and plan innovators for potential takeover. With senior management ageing and retirement and the mobility of the younger workforce, the transfer of "how to get work done" processes is being lost. Crisis leadership is in (Rothwell, 2001).

The consistency of the working relationship between entrepreneurs and workers is not predictable. Limitations and the unforeseeable essence of workers in this situation include the eventual termination of service (retirement), resignation, dismissal and death. None of these would throw a properly designed organization out of gear, as there would be well-established procedures in place to tackle these risks and organizational management unpredictability. On the basis of how critical the job is, there is a concerted and systematic effort to get people ready to take up positions, usually at the management level, so that none of the above shocks the company.

Knowledge in succession planning has grown to include an understanding of the "leadership" behaviours and core competencies that future candidates may have. In addition, scholars and companies have recognized that the value of success lies not only in the highest positions but also in the operations of the company. 'Organizations are usually confronted with the need to replace important executive personnel in a relatively short time frame due to rapid changes in acquisitions, downsizing, mergers, re-engineering and re-engineering. There is also an increasing demand for qualified and talented individuals.' (Orellano: 1997) Without the advancement of leadership around the organization, and not just at the forefront of business, the implementation is crucial.

At the centre of succession planning is the quest for internal regulatory structures to recognize new workers who are already familiar with the organizational culture. Continuing succession planning ensures that workers are continually educated and prepared to fill any potential vacancies. When the company expands, the loss of key workers becomes inevitable. This, however, offers advertising incentives and enhances revenue. Succession preparation assures workers who are quickly prepared, ready to fill empty and challenging positions. Succession preparation enhances the availability of skilled and qualified workers who are 


\section{International Journal of Social Sciences and Management Review}

prepared to fill vacancies. Good succession or talent pool management is concerned with creating a variety of feeder groups up and down the entire chain or advancement of leadership (Charm et al. 2001).

The fundamental principle behind the succession-management process is that top organizational talent must be handled for the better benefit of the company. Merck and other organizations (2013) claim that in order to be successful; a "talent mindset" must be part of the leadership culture.

\subsection{LITERATURE REVIEW}

\section{Perspectives on Succession Planning}

According to Marshall Goldsmith (2007), succession planning is a process in which the company embarks on a strategic plan to hire and retain employees to take on key roles in the company. Using the succession planning framework, you employ, develop their experience, skills and knowledge and train them on promotion or advancement to more demanding positions. He emphasized that consistently implementing succession planning ensures that workers are continually trained to serve any required function. As companies or organizations expand, provide promotional incentives, lose key staff, and boost revenue, the succession planning ensures that you have workers ready and willing to serve new positions.

In the words of Charan et al (2001), succession planning continues to perpetuate the enterprise, filled up with high-performance employees to ensure that a variety of such performers are chosen for every stage of leadership. From this point of view, succession planning is seen as a management pipeline that accelerates the efficiency of management over time. Charan 's interpretation looks forward to the future, and this is likely to influence Scharmer's (2007) statement that succession planning co-creates a transformational process in which management takes into consideration the prospect. Succession planning is a systematic process that involves identifying and training possible successors to take on a new task (Garman and Glawe, 2004). Nevertheless, this definition is short and lightweight, but in contrast with Charan's definition, it is not futuristic and lacks energy. The Quality and Participation Journal (2005) stated that 67 per cent of businesses do not have a succession plan and 45\% do not have an administrative development strategy in place and it has been contended that succession training programs could alleviate the crisis (Khumalo and Harris, 2008).

Sparrow (1992) further states that "Human Resource Planning (HRP) discusses problems at the core of the market, such as decentralization control, acquisition, technology or internationalization, and examines the consequences of human resource management. Santorin (2004) argued that, in the light of a pressing business issue, HRP also needs a systematic approach to hiring, creating, managing and empowering employees within the organisation.

It's a structured method of connecting human resource activities with market demands to maximize the abilities of an organization. It sets out the strategies, courses of action and goals for the range of policies needed to allow the company to influence its human resource 


\section{International Journal of Social Sciences and Management Review}

management. According to Rothwell, "Succession Planning is, therefore, better understood as any initiative designed to ensure that an agency, division, department, or working group continues to function effectively by preparing for the growth, succession, and strategic implementation of key people over time."

\section{Five Key Elements of the Succession Planning Process}

Preparation for Succession is not just about replacing an existing employee. The main goal is to get the business ready for future organizational needs and to improve its "bench power." There are five principal elements when dealing with each succession period.

\section{Identification of Key Positions Needed to Implement a Succession Plan}

The institution could have a few critical positions, or it could have several of them. The role of the general manager of staff is certainly one that must be included in the succession plan. Consider the following when deciding which to include:

i. Is this a crucial function of the operation of the business and if the person vacates or is inactive in that function suddenly and the position is vacant, then the institution will be at a disadvantage?

ii. Is this a rational next step? Many companies may concentrate on senior managers or subordinates as the second level of succession management (after the CEO, who is the first level).

iii. Does a lot of information currently exist in that place of processes or other institutional memory that is lost when the incumbent leaves work? It doesn't report work procedures and results in full, for example.

Identification of the successor or successors

The company could have more than one staff member who has demonstrated the expertise, abilities, ability and desire to achieve a degree of additional responsibility. The dedication and skill of the succession nominee to the process is an important part of the identification of how to create.

Identification of job requirements

The aim is to consider the conditions that will occur in the future in one or more major role. It thus creates a supply of strengths and skills to audit what a succession applicant provides and needs to improve.

iv. Building competencies

Capacity building and capacity building will focus on the current and future organizational needs of succession planning processes. It was quite correct to say that "what's next" is not the issue of succession planning?" There should be a collection of 


\section{International Journal of Social Sciences and Management Review}

competencies (i.e. experience, abilities and skills) for each role. However, for each succession candidate, there must be different planning plans for the creation of a development plan to prepare the competencies of the succession candidates for the potential position envisaged.

\section{v. Progress Assessment}

It is important for an organization which develops a plan for succession and invests in the development of its employees to measure its progress towards the expected result. This is a good thing, says Modern Management founder Peter F. Drucker (2002).

\section{Planning of a Succession Plan}

Institutional leaders who are interested in succession planning are the Board of Directors, the Chief Executive Officer and, by delegation, the other personnel that oversee the executive. The Board is active in establishing organizational principles and creating a community that ensures that succession planning takes place. The Board must keep the Chief Staff Officer responsible for the preparation of succession. The Board also has to devote the required money. The Chief Staff Officer will be the person who provides guidance for staff to improve workers and ensures that succession plans are drawn up, reviewed, evaluated and modified to ensure that the company is able to track that its succession planning investment pays dividends. Many managers are interested in managing their best employees and following a focused, purposeful approach to teaching, mentoring, directing and improving their workers in order to improve their skills by different means, one of which would be training.

\section{Developing Employees for Succession Planning}

Building the right pool of employees and the organization requires, for its succession plan, that you use practices such as assignment to specific projects, team leadership roles, lateral and both external and internal training and development opportunities. Gross, (1968) thought that while you're starting a succession plan, you ought to keep superior and experienced workers because they value your focus, time and growth. Hazarika, (2009) argued that workers are engaged and inspired when their continued growth and development is made clear to them. Succession planning can be effectively achieved in an organization when the long terms goals are being clearly defined and superior staffs are hired.

The development needs of your employees must be identified and well understood. Career directions and positions for workers to be filled must be clearly conveyed to them. You need to concentrate money on the retention of key employees. Do you know who's going to take the Chief Executive's place if the CEO has a sudden heart attack?

Will you have the next generation of leaders ready to serve those positions if your top executives are taken away from another firm? If not, you can end up with under-qualified workers going into leadership positions, so no one is better off taking over.

The best solution for lost leadership is a clear succession planning system, recognizing and supporting the next generation of leaders through guidance, preparation and stretch 


\section{International Journal of Social Sciences and Management Review}

assignments. They are ready to take the lead when it comes time. Research promotes a sound plan for succession. A few years ago, the consultancy firm Booz Allen Hamilton's research reached the conclusion that "when it comes to returning to shareholders, inside nominated CEOs tend to outperform others." Many organizations are struggling to go beyond a statistical list of names for a few top positions in their succession planning programs.

"Every company has a succession planning document," Butterfield (2008) stated that such succession planning provides a framework for human resources leaders and advice on how to create a strong succession planning system that aligns talent management with the company's vision, ensures that workers can develop their leadership skills and ensures that the organization has a leadership plan in place for them.

This was a reasonable concern because Skinner only arrived in 2005 following the unforeseeable death of two other CEOs in two years. And then Skinner was assured when he retired in 2012, that Don Thompson was able to take over his successor in the Chief Operating Officer because he spent many of his seven years coaching him.

"I thought essentially that it was the duty of the Board of Directors to make sure that I gave them someone else could manage the business while I was gone," Skinner said to Fortune a year before he retired. "I wouldn't have quit until I was able to do that." A crucial component of succession planning is this sort of leadership level dedication to preparing and mentoring the next generation. And while most executives understand the importance of succession planning efforts, few believe that in this category, their organization stands out.

\section{Existence of Succession planning policy}

This study dealt with the nature of succession planning policy on the basis of various models created. The implementation of these models in different organisations reflects the existence of succession planning policies.

Santorini (2004, p. 158) created the first succession model referred to as "Relay Succession Planning." Under this model, he proposed that the outgoing Chief Executive Officer (CEO) of the company should turn over the baton to the successor for a long period of time.

The effect of the businesses that followed the Santorin model has been measured and contrasted with organizations that do not have these models in place. Organizations that execute relay succession plans have been shown to have performed better as successors have been exposed to business problems and have been able to resolve these problems in the presuccession process.

In fact, the companies that adopted the relay succession model performed better in the postsuccession process, as successors were tried and checked, which means that experience would speak for them. Scharmer (2007) also created a second succession model called "Scharmer's Theory U Model." He affirms that the senior management team supports and participates in succession planning. In the first case, this model sees succession planning as beginning from the near future and supports the concept of a five-move $U$ system that can bring about change (Scharmer, 2007). What are the movements; co-initiating - organization 


\section{International Journal of Social Sciences and Management Review}

at this stage, in the words of Scharmer, establishes a common purpose for a future event with all stakeholders.

- Co-sensing - is the second stage of the movement in which the organization sees the need to work together across borders. Around the same time, new concepts and inventions are taking place by collective feedback.

- The stage 3 is Presencing, where the company's leadership begins to recognize the prospect they envisage (Scharmer, 2007). This revolutionary strategy lays the foundation for progress, stimulating the company to the desired end. It is therefore observed at this point that leadership has let go of unresolved past issues and is looking to a more optimistic future.

- The fourth in this framework is 'co-creating' - Scharmer (2007) argues that organizational leadership is exploring the future at this point, and prototyping what the future might look like. He goes on to suggest that leaders should develop a longterm concept of planning for succession rather than working on immediate organizational needs. In addition, Kartz (2006) posits that for a successful and effective succession plan to be in effect, there is a need to assess the organization's strategy and policy that emphasizes the successor's credentials needed.

- The fifth phase of Scharmer in Theory U stage 'co-evolving' will allow an institution to accept change and incorporate succession planning strategies in the light of an uncertain future (Scharmer, 2007).

The existence of these models according to Santorin and Scharmer has been tried and tested in various companies and have confirmed the realities of the existence of succession planning policies.

\subsection{METHODOLOGY}

A case study approach was adopted to provide a rich understanding of how succession planning is used as a tool to develop an organization in a real-life context. The study used both primary and secondary data. Interviews and questionnaires were used for data collection. The target population for the study involves all members of staff of the University of Education, Winneba - Kumasi, Ghana. The college has four faculties, a number of departments and units with a total membership of the staff population of 403. To obtain the sample size for the study, the simple random sampling technique was used. The selection was then done by random picking. In all, the study considered hundred (100) employees out of which twenty (20) represented views of senior management, forty (40) represented the view of senior staff members and forty (40) represent the views of junior staff members. The collected data were analysed using the Statistical Package for Social Science (SPSS) software.

\subsection{RESULTS AND DISCUSSIONS}




\section{International Journal of Social Sciences and Management Review}

\section{Existence of Succession Planning Policy at UEW - K}

As shown, table 1.1 is the result of responses from respondents regarding the existence of a succession planning policy at UEW-K. The table shows that $60(75 \%)$ of the respondents responded 'Yes' to the existence of a succession planning policy at UEW-K. However, 3 (3.8\%) respondents stated 'No' to the existence of a succession planning policy in the institution.

It is worthy of note that $17(21.2 \%)$ of the respondents were not aware of the existence of such a policy.

Table 1.0

Responses on the existence of a succession planning policy at UEW-K

\begin{tabular}{|l|l|l|l|l|l|l|l|}
\hline Designation & SMM & SSM & JSM & $\begin{array}{l}\text { Overall \% } \\
\text { response }\end{array}$ \\
\hline Variables & Freq. & Per. & Freq. & Per & Freq. & Per. & $60(75 \%)$ \\
\hline Yes & 14 & 70 & 25 & 69 & 21 & 87.5 & $3(3.8 \%)$ \\
No & 2 & 10 & 1 & 3 & - & - & 13 \\
Not Aware & 4 & 20 & 10 & 28 & 3 & 13 & $17.2 \%)$ \\
TOTAL & $\mathbf{2 0}$ & $\mathbf{1 0 0}$ & $\mathbf{3 6}$ & $\mathbf{1 0 0}$ & $\mathbf{2 4}$ & $\mathbf{1 0 0}$ & $\mathbf{8 0}(\mathbf{1 0 0} \%)$ \\
\hline
\end{tabular}

Key: SMM= Senior Management Members, SSM= Senior Staff Members, JSM= Junior Staff Members

Source: Researcher's own work 2014

\section{Succession planning practices in UEW-K}

The respondents were asked to indicate the succession planning practices adopted in the institution specifically in relation to Job Rotation, Job Shadowing, Executive Coaching, Mentoring and Training and Development

Presented in figure 1.0 below is a representation of the responses given by the respondents

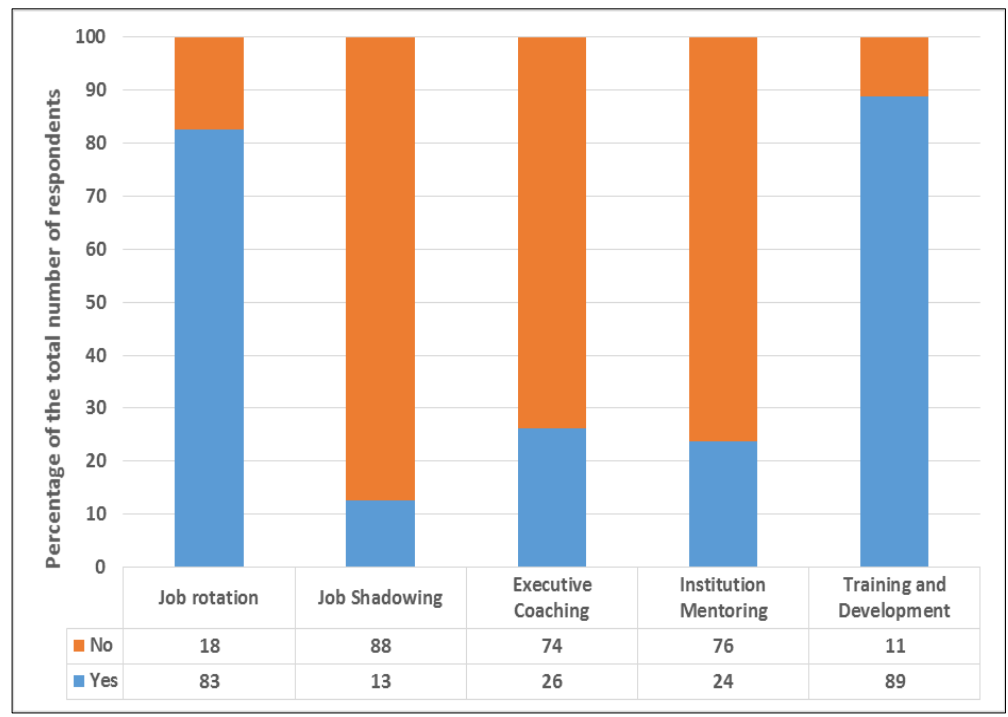

Source: Researchers' own work 2014

Figure 1.0 A chart showing responses on succession planning practices at UEWK 


\section{International Journal of Social Sciences and Management Review}

From figure 1.0, it could be observed that $66(83 \%)$ of the respondents responded 'Yes' as against $14(18 \%)$ who responded 'No' to the use of job rotation as a succession planning practice adopted by the University.

On the contrary, $70(88 \%)$ of the respondents responded 'No' to the use of Job Shadowing for identifying and preparing potential successor to assume new role in the organization. It must be said that $10(13 \%)$ respondents, on the other hand, declared in the affirmative to the use of job shadowing for succession in the University.

More so, regarding executive coaching, almost two-thirds representing 59 (74\%) of the respondents declined to the assertion of the use of executive coaching as succession planning strategy in filling key positions in the institution. On the other hand, 21 (26\%) of the respondents affirm to the use of executive coaching as a succession planning practice by the University.

In addition, majority of the respondents comprising 51 (76 $\square$ ) of the respondents said 'No' to the use of mentoring as a succession planning practice adopted by the University. On the contrary, $19(24 \%)$ of the respondents responded 'Yes' to the use of such strategy by the infilling important positions in the institution.

Furthermore, regarding training and development as a succession planning practice by the University, overwhelming number comprising 71 (89\%) of the respondents said 'Yes' to the use of training and development as a succession planning strategy in recruiting individuals to occupy key positions in the University. On the other hand, 9 (11\%) of the respondents said no to the use of training and development as succession planning practice by the University.

\section{Benefits of Succession Planning}

The respondents were given some items against which they were supposed to indicate some of the benefits they think the university is deriving from implementing succession planning policies in filling key vacant designations in the organization. From the responses as shown in table 1.2, it could be observed that $52(65 \%)$ of the respondents responded 'Yes' to the assertion that the benefits from succession planning by way of ensuring that the institution is prepared with a plan to support service continuity when key people leave.

On the option of succession planning ensuring a continuing supply of qualified, motivated people who are prepared to take over when the current senior staff and other key employees leave the institution in variable B, more than two-thirds $61(76 \%)$ of the respondents responded 'Yes' to this effect. Meanwhile, 19 (24\%) of the respondents responded 'No' which implies a disagreement.

From variable C, $41(51 \%)$ of the respondents responded 'Yes' to the statement that the institution stands to benefit from succession planning as an alignment between the institution's vision and human resources that demonstrates an understanding of the need to have appropriate staffing to achieve strategic plans. On the contrary, 39 (49\%) of the respondents responded 'No' thereby disagreeing to that effect. 


\section{International Journal of Social Sciences and Management Review}

Moreover, variable D, indicates that more than half of the respondents 47 (59\%) responded 'No' which suggest that the respondents disagreed with the assertion that succession planning serves as a commitment to developing career paths for employees which will facilitate the institution's ability to recruit and retain top-performing employees. However, only 33 (41\%) of the respondents responded 'Yes' thus agreeing.

Again, 46 (58\%) of the respondents reported that succession planning does not benefit the university or institution by way of serving as an external reputation as an institution that invests in its people and provides opportunities and support for advancement. On the other hand, only $34(42 \%)$ of the respondents were convinced that the institution benefits in this regard.

On the question of succession planning being a message to the employees that they are valuable from variable $\mathrm{F}$, majority of the respondents $46(57 \%)$ also were not convinced that having a succession plan will send a message to the employees that they are valuable.

Table 1.1

Benefits of Succession Planning to the University

\begin{tabular}{|c|c|c|c|c|c|c|c|}
\hline & \multicolumn{2}{|c|}{ SMM } & \multicolumn{2}{|l|}{ SSM } & \multicolumn{2}{|l|}{ JSM } & \multirow{2}{*}{$\begin{array}{l}\text { Total frequency } \\
(\%)\end{array}$} \\
\hline Benefits & Freq. & Per. & Freq. & Per. & Freq. & Per. & \\
\hline \multicolumn{8}{|c|}{$\begin{array}{l}\text { A: A means of ensuring the institution is prepared with a plan to support service continuity } \\
\text { when the executive directors, senior managers or key people leave. }\end{array}$} \\
\hline Yes & 16 & 80 & 25 & 69 & 11 & 46 & $52(65 \%)$ \\
\hline & 4 & 20 & 11 & 31 & 13 & 54 & $28(35 \%)$ \\
\hline TOTAL & 20 & 100 & 36 & 100 & 24 & 100 & $80(100 \%)$ \\
\hline
\end{tabular}

B: A continuing supply of qualified, motivated people, who are prepared to take over when current senior staff and other key employees leave the institution.

\begin{tabular}{l|l|l|l|l|l|l|l} 
Yes & 13 & 65 & 30 & 83 & 18 & 75 & $61(76 \%)$ \\
No & 7 & 35 & 6 & 17 & 6 & 25 & $19(24 \%)$ \\
TOTAL & $\mathbf{2 0}$ & $\mathbf{1 0 0}$ & $\mathbf{3 6}$ & $\mathbf{1 0 0}$ & $\mathbf{2 4}$ & $\mathbf{1 0 0}$ & $\mathbf{8 0}(\mathbf{1 0 0 \%})$
\end{tabular}

C: An alignment between your institution's vision and human resources that demonstrates an understanding of the need to have appropriate staffing to achieve strategic plans.

\begin{tabular}{l|l|l|l|l|l|l|l|}
\hline Yes & 8 & 40 & 19 & 53 & 14 & 58 & $41(51 \%)$ \\
No & 12 & 60 & 17 & 47 & 10 & 42 & $39(49 \%)$ \\
TOTAL & $\mathbf{2 0}$ & $\mathbf{1 0 0}$ & $\mathbf{3 6}$ & $\mathbf{1 0 0}$ & $\mathbf{2 4}$ & $\mathbf{1 0 0}$ & $\mathbf{8 0}(\mathbf{1 0 0 \%})$ \\
\hline
\end{tabular}

D: A commitment to developing career paths for employees which will facilitate your institution's ability to recruit and retain top-performing employees.

\begin{tabular}{l|l|l|l|l|l|l|l} 
Yes & 8 & 40 & 16 & 44 & 9 & 38 & $33(41 \%)$ \\
No & 12 & 60 & 20 & 56 & 15 & 63 & $47(59 \%)$ \\
TOTAL & $\mathbf{2 0}$ & $\mathbf{1 0 0}$ & $\mathbf{3 6}$ & $\mathbf{1 0 0}$ & $\mathbf{2 4}$ & $\mathbf{1 0 0}$ & $\mathbf{8 0}(\mathbf{1 0 0 \%})$ \\
\hline
\end{tabular}

E: An external reputation as an institution that invests in its people and provides opportunities and support for advancement.

\begin{tabular}{l|l|l|l|l|l|l|l} 
Yes & 6 & 30 & 17 & 47 & 11 & 46 & $34(42 \%)$ \\
No & 14 & 70 & 19 & 53 & 13 & 54 & $46(58 \%)$ \\
TOTAL & $\mathbf{2 0}$ & $\mathbf{1 0 0}$ & $\mathbf{3 6}$ & $\mathbf{1 0 0}$ & $\mathbf{2 4}$ & $\mathbf{1 0 0}$ & $\mathbf{8 0}(\mathbf{1 0 0 \%})$ \\
\hline
\end{tabular}

F: A message to your employees that they are valuable 


\section{International Journal of Social Sciences and Management Review}

Volume: 03, Issue: 04 "July - August 2020"

ISSN 2582-0176

\begin{tabular}{|l|l|l|l|l|l|l|l|}
\hline Yes & 6 & 30 & 17 & 47 & 11 & 46 & $34(43 \%)$ \\
No & 14 & 70 & 19 & 53 & 13 & 54 & $46(57 \%)$ \\
TOTAL & $\mathbf{2 0}$ & $\mathbf{1 0 0}$ & $\mathbf{3 6}$ & $\mathbf{1 0 0}$ & $\mathbf{2 4}$ & $\mathbf{1 0 0}$ & $\mathbf{8 0 ( 1 0 0 \% )}$ \\
\hline
\end{tabular}

Key: SMM= Senior Management Members, SSM= Senior Staff Members, JSM= Junior Staff Members

\section{Source: Researcher's own work 2014}

The respondents were asked to indicate whether they have personally benefitted from the practices of succession planning in the institution. The responses as being shown in figure 1.1 below indicate that overwhelming 59 (74\%) of the respondents responded 'Yes' to have benefitted personally from the succession planning policy in the institution. On the contrary only $6(7 \%)$ of the respondents responded 'No'. Quite a significant percentage, that is 15 $(19 \%)$ of the respondents failed to respond to the question.

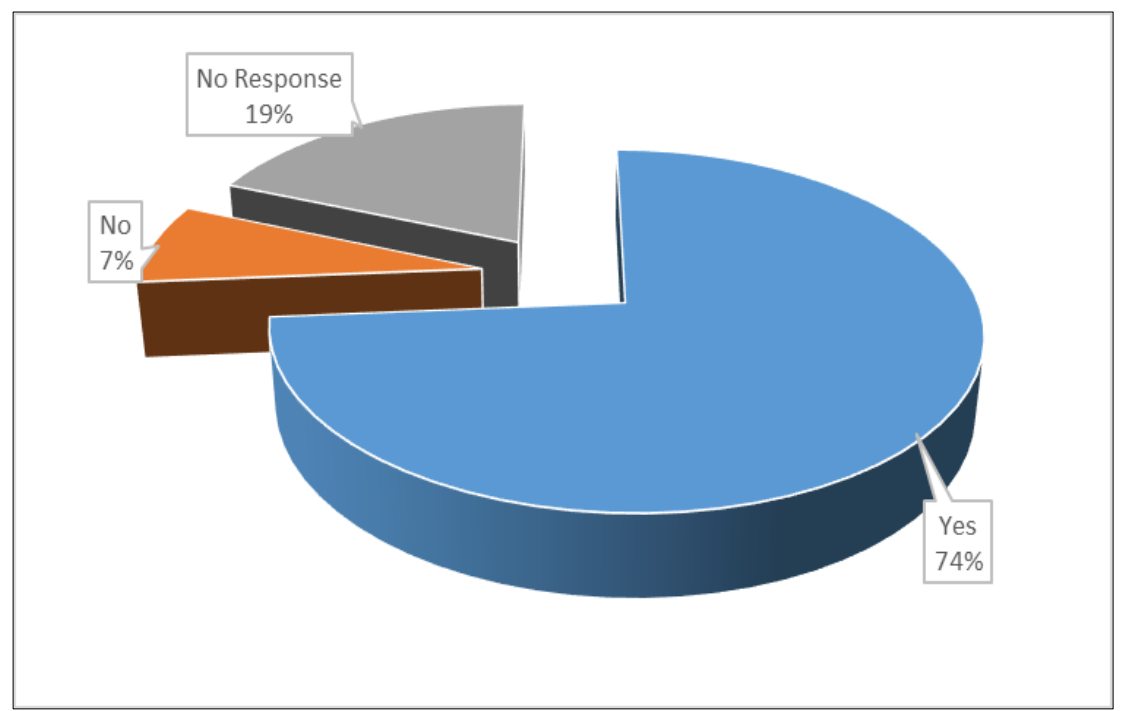

Figure 1.1 Number of respondents who have benefitted from Succession Planning

Source: Researcher's own work 2014

Table 1.2

Succession Planning Practices that has benefited respondents the most

\begin{tabular}{|l|l|l|}
\hline Program & Frequency & Percent \\
\hline Job Rotation & 53 & 34 \\
Job Shadowing & 5 & 3 \\
Executive Coaching & 19 & 12 \\
Institution Mentoring & 19 & 12 \\
Training and Development & 62 & 39 \\
\hline TOTAL & $\mathbf{1 5 8}$ & $\mathbf{1 0 0}$ \\
\hline
\end{tabular}

\section{Source: Researcher's own work 2014}

In table 1.2, the respondents were asked to indicate as many as applicable in the case of the Succession Plans programmes they have benefitted the most. Analysis of the responses 


\section{International Journal of Social Sciences and Management Review}

showed more than one-third $62(39 \%)$ of the total responses indicated benefitting the most from the Training and Development programmes organized by the university. Further, 53 (34\%) have benefitted from the Job Rotation practices adopted by the institution as a way of filling key positions in the institution. It is worthy of note that there were an equal number of responses for Executive Coaching and Institution Mentoring both with few responses of 19 $(12 \%)$ each. The table further reveals that there is the little benefit derived from the use of Job Shadowing with responses of $5(3 \%)$.

\section{Criteria for selecting Successors in the Institution}

Questions concerning policy framework and implementation were left for senior members and staff only to answer. In table 1.3, the availability of a selection criterion for succession planning was taken into consideration. The study showed that $20(43 \%)$ respondents said 'Yes' to the existence of a selection criterion designed for the use of recruiting employees to fill key positions. However, $18(38 \%)$ were not aware of the existence of any selection criteria. 9 (19\%) of the respondents denied the existence of any selection criterion of that sort.

Table 1.3

Existence of criterion for selecting a successor at UEW-K

\begin{tabular}{|c|c|c|c|c|c|}
\hline \multirow{2}{*}{ Responses } & & \multicolumn{3}{|c|}{ Designation } & \multirow[b]{2}{*}{ Total } \\
\hline & & SMM & SSM & JSM & \\
\hline \multirow[t]{2}{*}{ Yes } & Frequency & 8 & 8 & 4 & 20 \\
\hline & $\%$ within designation & $42.1 \%$ & $44.4 \%$ & $40.0 \%$ & $43 \%$ \\
\hline \multirow[t]{2}{*}{ No } & Frequency & 5 & 1 & 3 & 9 \\
\hline & $\%$ within designation & $26.3 \%$ & $5.6 \%$ & $30.0 \%$ & $19 \%$ \\
\hline \multirow[t]{2}{*}{ Not aware } & Frequency & 6 & 9 & 3 & 18 \\
\hline & $\%$ within designation & $31.6 \%$ & $50.0 \%$ & $30.0 \%$ & $38 \%$ \\
\hline \multirow[t]{2}{*}{ Total } & Frequency & 19 & 18 & 10 & 47 \\
\hline & $\%$ within designation & $100.0 \%$ & $100.0 \%$ & $100.0 \%$ & $100.0 \%$ \\
\hline
\end{tabular}

Key: SMM= Senior Management Members, SSM= Senior Staff Members, JSM= Junior Staff Members

Source: Researcher's own work 2014

\section{Criterion stages for selecting successors in UEW-K}

The respondents were allowed to express themselves regarding how they consider the successor selection criteria are outlined in UEW-K. There were a total of 20 respondents who responded 'Yes' to have a criterion for selecting potential successors. The outcome showing in figure 1.3 below shows that 12 respondents stated that the potential successors are taken through vetting and then interview.

Six respondents, on the other hand, stated that there is a performance assessment of the potential candidates. However, 2 respondents out of the 20 were not sure what the potential successors go through. 


\section{International Journal of Social Sciences and Management Review}

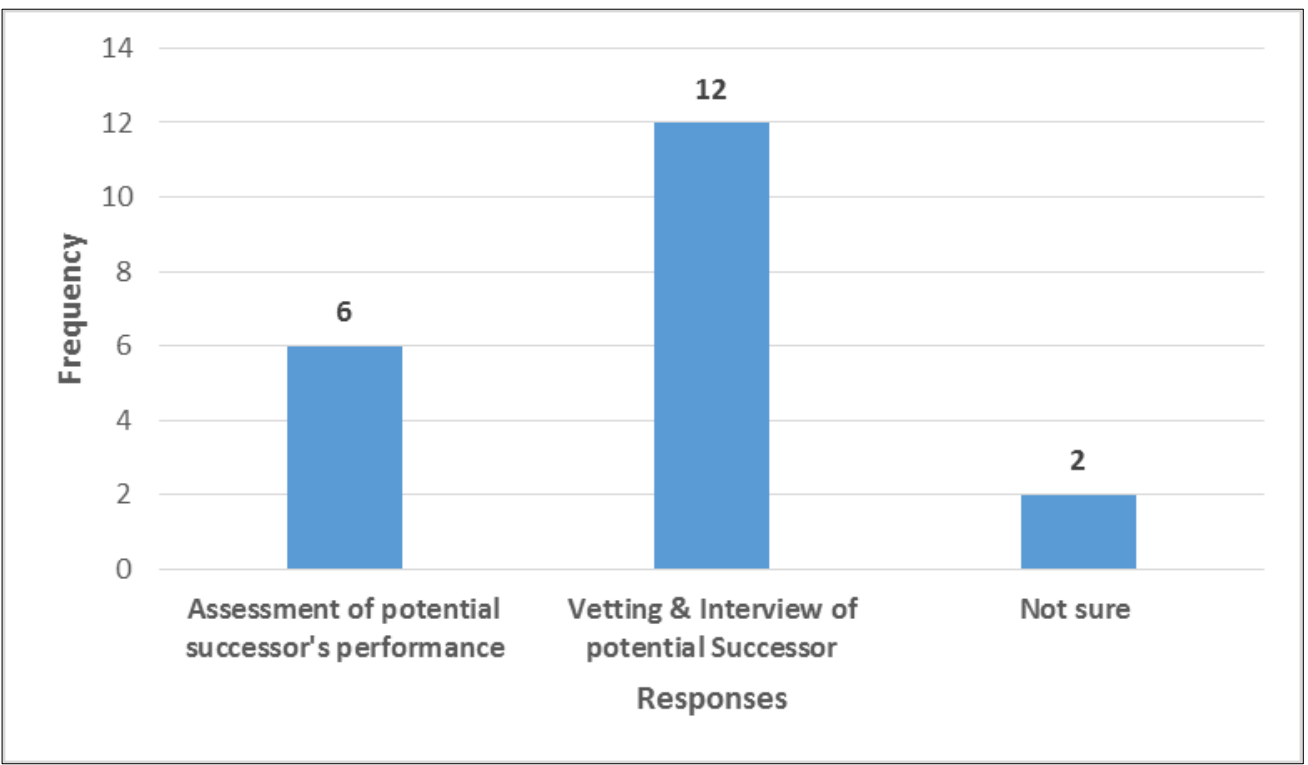

Figure 1.3 Succession criteria used in UEW-K

Source: Researcher's own work 2014

\section{Personality traits as selection criteria for succession planning}

Table 1.4 presents a matrix of the responses given by senior members and senior staff members on the personally traits they look for when selecting a successor for key positions. The results show that out of a total of 56 responses 54 (96\%) of the respondents consented to the fact that they consider the potential successor's 'ability to work'. The senior members and senior staff consider potential successors who are hardworking as almost all of them 53 $(95 \%)$ reported. Majority of the senior members and senior staff 47 (84\%) take into consideration the 'Intelligence' of the potential successor with more than half of the respondents $30(54 \%)$ opting to look at the 'Broadmindedness' of the potential successor to a key position in the institution. In addition, more than half of the respondents $32(57 \%)$ consider potential candidates who are 'Straightforward' whereas the results also shows that they consider the 'Competencies' of the candidate for the position as $36(64 \%)$ of the respondents reported. More than half of the respondents $30(54 \%)$ look at other personality traits possessed by the potential successor to a key position.

On the contrary, the results further showed that respondents do not take into consideration the potential successor's desire to stay in the institution as $31(55 \%)$ which forms more than half of the respondents reported. Again, 33 (59\%) of members do not take into consideration the Inspirational abilities of the potential candidate.

Thirty-two (57\%) senior management and staff members surveyed reported that they do not consider potential candidates who are fair-minded to occupy key positions in the institution.

Table 1.4

Personality traits Senior Members look out for in a potential successor 


\section{International Journal of Social Sciences and Management Review}

Volume: 03, Issue: 04 "July - August 2020"

ISSN 2582-0176

\begin{tabular}{|c|c|c|c|c|c|}
\hline \multirow[b]{2}{*}{ Personality traits } & \multicolumn{2}{|l|}{ SMM } & \multicolumn{2}{|l|}{ SSM } & \multirow{2}{*}{$\begin{array}{ll}\text { Overall } & \% \\
\text { response } & \end{array}$} \\
\hline & Freq. & Per. & Freq. & Per. & \\
\hline \multicolumn{6}{|l|}{ 1. Ability to work } \\
\hline Yes & 19 & 95 & 35 & 97 & $54(96 \%)$ \\
\hline No & 1 & r5 & 1 & 3 & $2(4 \%)$ \\
\hline TOTAL & 20 & 100 & 36 & 100 & $56(100 \%)$ \\
\hline \multicolumn{6}{|c|}{ 2. Desire to stay in the institution } \\
\hline Yes & 9 & 45 & 16 & 44 & $25(45 \%)$ \\
\hline No & 11 & 55 & 20 & 56 & $31(55 \%)$ \\
\hline TOTAL & 20 & 100 & 36 & 100 & $56(100 \%)$ \\
\hline \multicolumn{6}{|l|}{ 3. Hardworking } \\
\hline Yes & 19 & 95 & 34 & 94 & $53(95 \%)$ \\
\hline No & 1 & 5 & 2 & 6 & $3(5 \%)$ \\
\hline TOTAL & 20 & 100 & 34 & 100 & $56(100 \%)$ \\
\hline \multicolumn{6}{|l|}{ 4. Intelligent } \\
\hline Yes & 16 & 80 & 31 & 86 & $47(84 \%)$ \\
\hline No & 4 & 20 & 5 & 14 & $9(16 \%)$ \\
\hline TOTAL & 20 & 100 & 36 & 100 & $56(100 \%)$ \\
\hline \multicolumn{6}{|l|}{ 5. Broadminded } \\
\hline Yes & 10 & 50 & 20 & 56 & $30(54 \%)$ \\
\hline No & 10 & 50 & 16 & 44 & $26(46 \%)$ \\
\hline TOTAL & 20 & 100 & 36 & 100 & $56(100 \%)$ \\
\hline \multicolumn{6}{|l|}{ 6. Inspiring } \\
\hline Yes & 10 & 50 & 13 & 36 & $23(41 \%)$ \\
\hline No & 10 & 50 & 23 & 64 & $33(59 \%)$ \\
\hline TOTAL & 20 & 100 & 36 & 100 & $56(100 \%)$ \\
\hline \multicolumn{6}{|l|}{ 7. Fair-minded } \\
\hline Yes & 11 & 55 & 13 & 36 & $24(43 \%)$ \\
\hline No & 9 & 45 & 23 & 64 & $32(57 \%)$ \\
\hline TOTAL & 20 & 100 & 36 & 100 & $56(100 \%)$ \\
\hline \multicolumn{6}{|l|}{ 8. Straightforward } \\
\hline Yes & 12 & 60 & 20 & 56 & $32(57 \%)$ \\
\hline No & 8 & 40 & 16 & 44 & $24(43 \%)$ \\
\hline TOTAL & 20 & 100 & 36 & 100 & $56(100 \%)$ \\
\hline \multicolumn{6}{|l|}{ 5. Competent } \\
\hline Yes & 12 & 60 & 24 & 67 & $36(64 \%)$ \\
\hline No & 8 & 40 & 12 & 33 & $20(36 \%)$ \\
\hline TOTAL & 20 & 100 & 36 & 100 & $56(100 \%)$ \\
\hline \multicolumn{6}{|l|}{ 5.Others } \\
\hline Yes & 10 & 50 & 20 & 56 & $30(54 \%)$ \\
\hline No & 10 & 50 & 16 & 44 & $26(46 \%)$ \\
\hline TOTAL & 20 & 100 & 36 & 100 & $56(100 \%)$ \\
\hline
\end{tabular}

Key: SMM= Senior Management Members, SSM= Senior Staff Members

Source: Researcher's own work 2014

Succession Planning programmes to develop employees 


\section{International Journal of Social Sciences and Management Review}

The senior members together with the senior staff members were to indicate the programmes designed to assist employees succeed in higher positions in the institution.

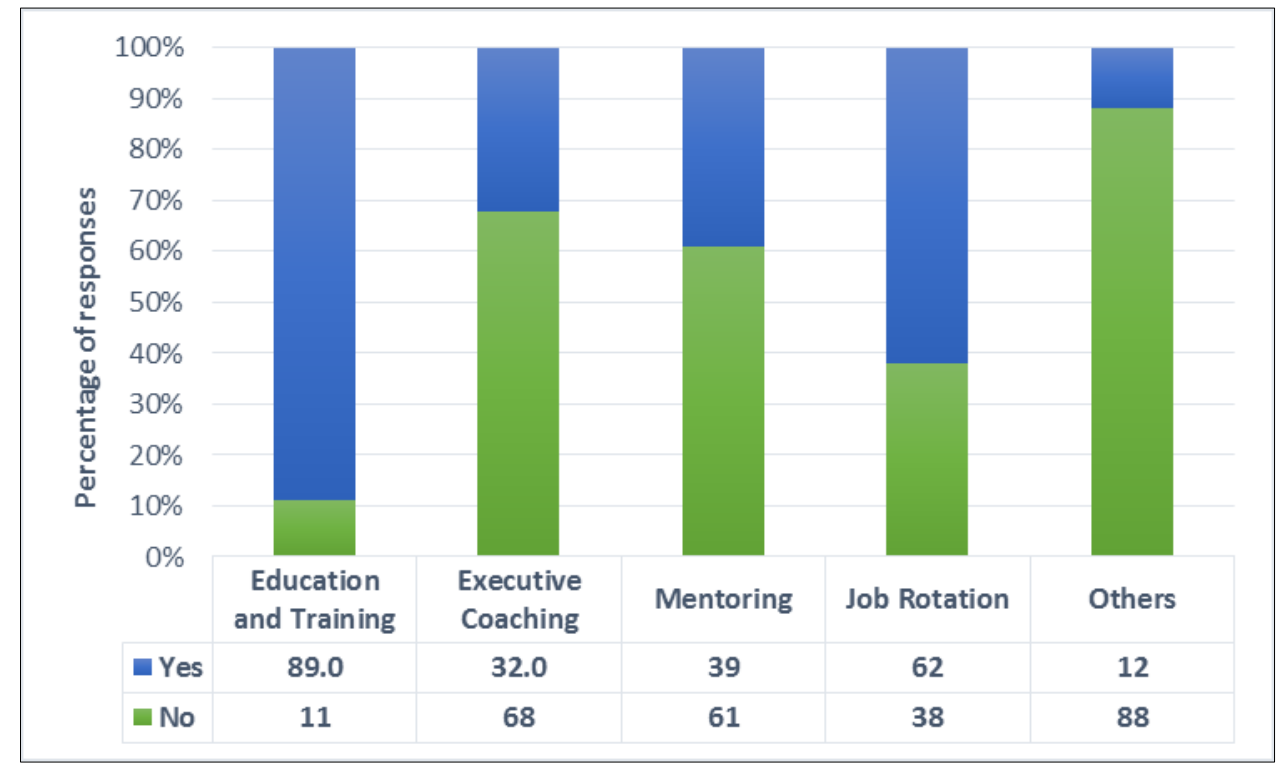

Figure 1.4 Programs in place to develop employees to take higher positions

Source: Researcher's own work 2014

From figure 1.4, $71(89 \%)$ of all the respondents said that education and training programmes have been instituted to assist the employees who take up higher positions to succeed.

Again, it could be observed that apart from the education and training, the institution has in place a Job rotation mechanism that is used to help the potential employee succeed in occupying a higher-level position in the organization as buttressed by $50(60 \%)$ of the senior management and staff members. However, there was little use for executive coaching, mentoring and other forms of succession planning practices as 30 (40\%) of the total respondents reported.

\section{Programmes mostly used to upgrade potential successors}

Programmes instituted to up-grade the potential successors to develop their competencies to occupy a key position was considered. In table 1.5 below, the respondents were charged to tick as many as applicable in their case the succession planning program mostly used for this endeavour. The results show that out of a total of 130 responses collated 50 (38\%) reported Education and Training as the most used program for developing the capacity of potential successors in the university. Again, further, observation revealed that 'other' programs of succession planning were used more with 25 (19\%) reporting. Job Rotation 23, (18\%), Mentoring 20, (15\%) and Executive Coaching 12, (9\%) were scarcely used to up-grade the potential successors.

Table 1.5

Programmes mostly used to up-grade potential successors 


\section{International Journal of Social Sciences and Management Review}

Volume: 03, Issue: 04 "July - August 2020"

ISSN 2582-0176

\begin{tabular}{|l|l|l|}
\hline Programme & Frequency & Percentage\% \\
\hline Education and Training & 50 & 38 \\
Executive Coaching & 12 & 9 \\
Mentoring & 20 & 15 \\
Job Rotation & 23 & 18 \\
Others & 25 & 19 \\
\hline TOTAL & $\mathbf{1 3 0}$ & $\mathbf{1 0 0}$ \\
\hline
\end{tabular}

Source: Researcher's own work 2014

\section{The Institution's sources of recruitment}

Recruitment practices mostly adopted by the infilling higher-level positions in the institution were considered by the researcher. Showing in table 1.6 below is the results of the responses given by the senior management and staff members of the institution. It could be observed that most of the key positions in the organizations are filled through Internal Recruitment processes as reported by the majority of the respondents approximately 39 (70\%). Only 10 $(18 \%)$ of the respondents reported of External Recruitment whereas the remaining 7 (12\%) stated that recruitment is done from both sources.

Table 1.6

Mostly used recruitment source by the designation of respondents

\begin{tabular}{|ll|l|l|l|}
\hline \multirow{2}{*}{ Source } & \multicolumn{2}{l|}{ Designation } & \multirow{2}{*}{ Total } \\
\cline { 3 - 5 } Internal Recruitment & SSM & SSM & 39 \\
& \% within Designation & $70.0 \%$ & $69.4 \%$ & $70 \%$ \\
External Recruitment & Frequency & 3 & 7 & 10 \\
& \% within Designation & $15.0 \%$ & $19.4 \%$ & $18 \%$ \\
Both & Frequency & 3 & 4 & 7 \\
& \% within Designation & $15.0 \%$ & $11.1 \%$ & $12 \%$ \\
\hline Total & Frequency & $\mathbf{2 0}$ & $\mathbf{3 6}$ & $\mathbf{5 6}$ \\
& \% within Designation & $\mathbf{1 0 0 . 0 \%}$ & $\mathbf{1 0 0 . 0 \%}$ & $\mathbf{1 0 0 . 0 \%}$ \\
\hline
\end{tabular}

Key: SMM= Senior Management Members, SSM= Senior Staff Members

Source: Researcher's own work 2014

\section{Challenges of succession planning}

Challenges to the successful implementation of the succession plans in the institution were also considered. The respondents were asked to indicate whether they encounter any difficulty in their bid to implement succession planning policy in the institution. From table 1.7 below, it could be deduced that an overwhelming number of the respondents $43(83 \%)$ consented to face challenges with the implementation of succession planning policy in the institution. However, only $9(17 \%)$ of them did not accept the notion that there are challenges as far as succession planning implementation is concerned. 


\section{International Journal of Social Sciences and Management Review}

Volume: 03, Issue: 04 "July - August 2020"

ISSN 2582-0176

Table 1.7

Challenges to succession planning in UEW-K by the designation of respondents

\begin{tabular}{|l|l|l|l|l|}
\hline \multirow{2}{*}{ Variables } & & Frequency \& percentages & Designation & \multirow{2}{*}{ Total } \\
\cline { 3 - 5 } & SMM & SSM & 43 \\
\hline Yes & Frequency & 15 & 28 & $83 \%$ \\
& No within Designation & $83.3 \%$ & $82.4 \%$ & 9 \\
& Frequency & 3 & 6 & $17 \%$ \\
\hline Total & \% within Designation & $16.7 \%$ & $17.6 \%$ & $\mathbf{5 2}$ \\
& Frequency & $\mathbf{1 8}$ & $\mathbf{3 4}$ & $\mathbf{1 0 0 . 0 \%}$ \\
\hline
\end{tabular}

Key: SMM= Senior Management Members, SSM= Senior Staff Members, JSM= Junior Staff Members

Source: Researcher's own work 2014

\section{Factors challenging the implementation of succession planning policies in UEW-K}

A host of factors were given out to respondents as many as are applicable in the university. The results showing in table 1.8 below indicate that 'Inability to adequately motivate and retain key employees' is one of the major factors challenging the implementation of succession planning policy in the as $38(21 \%)$ of the respondents declared. Moreover, 28 $(15 \%)$ pointed to the lack of financial resources as one of the main causes inhibiting the effective implementation of succession planning in the institution. Less than a quarter of the total responses 25 (14\%) reported being challenged by the 'size of the organization'. Inadequate training and development 23, (13\%), lack of company vision and failure to address future needs 24,( $13 \%)$ and Poor communication resulting in confusion 23, (13\%) were the other forms of challenges encountered by the senior management and staff members in their bid to implement the policy in the institution.

Table 1.8

Factors challenging the implementation of succession planning policies in UEW-K

\begin{tabular}{|l|l|l|}
\hline Challenges & Frequency & Percent \\
\hline Size of the organization & 25 & 14 \\
Lack of financial resources & 28 & 15 \\
Limited information about employees & 22 & 12 \\
Inadequate training and development & 23 & 13 \\
Lack of company vision and failure to address future needs & 24 & 13 \\
Poor communication resulting in confusion & 23 & 13 \\
Inability to adequately motivate and retain key employees & 38 & 21 \\
\hline TOTAL & $\mathbf{1 8 3}$ & $\mathbf{1 0 0}$ \\
\hline
\end{tabular}

Source: Researcher's own work 2014

Involvement in Succession Planning Policy Implementation in UEW-K 


\section{International Journal of Social Sciences and Management Review}

Figure 1.5 below is a clear indication that more than $63(79 \%)$ of the respondents are involved in the implementation of the succession planning processes in the institution. It is only a few that is $13(16 \%)$ of the respondents who are not involved in its implementation. It is worthy of note that $4(5 \%)$ of the respondents failed to attend to the question.

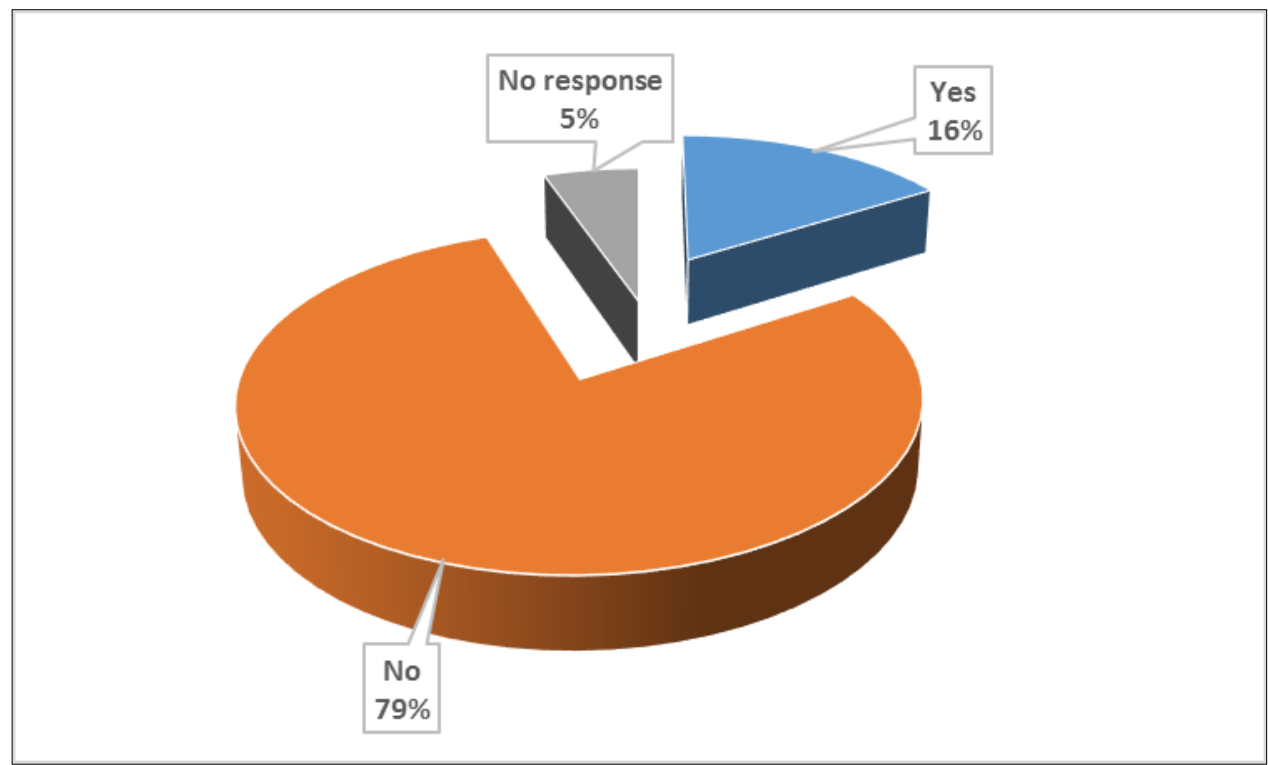

Figure 1.5 Respondents' involvement in Succession planning activities in UEW-K

Source: Researcher's own work 2014

\section{Implementation of succession policies in UEW-K}

Response from table 1.9 is a summary of the responses given by the respondents in relation to how succession plans can be implemented in UEW-K. Table 1.9 indicates that almost half 97 (49\%) of the respondents want a better employee motivation instituted in the institution whereas $47(24 \%)$ were of the opinion that improvement on the study leave structure will make people stay in the organization and go through the ranks to be able to fill key positions. Another way was for those involved in the implementation to identify the successors early with $31(16 \%)$ declaring.

\section{Table 1.9}

How succession plan policies can be implemented in UEW-K

\begin{tabular}{|l|l|l|}
\hline Responses & Frequency & Percent \\
\hline Intensify Education and Training of employees & 24 & 12 \\
Improvement on study leave structure & 47 & 24 \\
Early successor identification & 31 & 16 \\
Better employee motivation & 97 & 49 \\
\hline TOTAL & $\mathbf{1 9 9}$ & $\mathbf{1 0 0}$ \\
\hline
\end{tabular}

Source: Researcher's own work 2014

Succession planning policy in UEW-K 


\section{International Journal of Social Sciences and Management Review}

The results of the study have shown that the University of Education Winneba, - Kumasi campus has a laid out succession plan policy used in filling high-level positions in the institution. This is evidenced by the fact that exactly $60(75 \%)$ of the respondents reported that the institution has a succession plan policy (Table 1.1). In the opinion of the researcher, this finding proves to be a deliberate attempt on the part of the academic institution to develop core competencies in potential leaders to fill high-level positions within the institution. This finding, however, failed to confirm the findings of the Journal for Quality and Participation (2005) which reported that 54(67\%) of the respondents reported of their organizations not having succession plans. Khumalo and Harris, (2008) out of this then argued that this situation of not having succession plans in place could be alleviated by implementing succession training programmes. Succession planning activities in the being reduced to a policy statement only goes to make the planning activities very effective as opined by Rothwell, (2001, p. 23).

Moreover, succession planning practices adopted by the infilling important positions showed that it primarily resorts to the use of Job Rotation and Training and Development programs. This was the case when the majority of the respondents $66(83 \%)$ and $71(89 \%)$ respectively) responded to the use of these two programs as can be seen in figure 1.0.

It could be realised that there are little use of Job Shadowing, Executive Coaching and Mentoring programs for filling key roles in the University. This finding agrees with the works of Tropiano (2004), who stated that succession planning is a strategic, systematic and deliberate effort to develop competencies in potential leaders through the use of proposed learning experiences such as targeted rotations and educational training in order to fill highlevel positions without favouritism. To put this in HR perspective, this finding seems to satisfy the works of Santorin (2004) who maintained that Human Resource Planning requires a strategic approach to the recruitment, development, management and motivation of the people in the organization.

\section{The extent to which succession plan policies function in UEW-K}

In table 1.2 the result further demonstrates that the benefit from having a succession plan policy in place to see to the recruitment of employees to occupy important positions in the institution. This result is an indication of the fact that 52(65\%) of the respondents are of the opinion that the institution benefits from succession planning as it gives it an assurance that it is always prepared with a plan to support service continuity when key people currently occupying the important positions leave. That notwithstanding, succession planning helps the institution to ensure a continuing supply of qualified, motivated employees who are prepared to take over when the current senior staff and other key employees vacate their positions as reported by $61(76 \%)$ of the respondents.

According to the respondents, 41(51\%) reported that succession planning creates an alignment between the institution's vision and human resources that demonstrates an understanding of the need to have appropriate staffing to achieve strategic plans. This finding is a clear vindication of Butterfield (2008) who claimed that succession planning offers human resource leaders a framework on how to create a program that aligns talent management with the vision of the company thereby ensuring that employees have 


\section{International Journal of Social Sciences and Management Review}

development opportunities to hone their leadership skills. In the researcher's opinion, this offers the university an opportunity to easily and successfully fill key positions in the organizations.

Again, the respondents surveyed do not believe that succession planning in the University serves as a commitment to developing career paths for employees who will facilitate the institution's ability to recruit and retain top-performing employees (Table 1.2). In the researcher's opinion employees get the impression that such efforts on the part of the university are to tie them down to forcefully remain with the organization thereby making it difficult to move on their career paths. More so, this, however, does not reconcile fully with the works of Hazarika, (2009) who indicated that employees are motivated and engaged when they can see a career path for their continued growth and development. The finding that succession planning will not enhance the 's external reputation as an institution that invests in its people and provide opportunities and support for advancement as can be found in table 1.2 is rather surprising in the candid opinion of the researcher.

In general, this runs contrary to the works of Gross (1968) stating that through succession planning, an organisation is able to retain experienced, effective and efficient employees because they appreciate the time, attention and development the organization is investing in them.

This was further corroborated by the findings that having a succession plan will send a message to the employees that they are valuable as suggested by $46(57 \%)$ of the respondents surveyed (Table 1.2).

The use of succession planning in UEW-K was evident as the employees surveyed reported having personally benefited from the succession planning policies. Employees have benefitted the most from Training and Development and Job Rotational programs instituted by the university to augment their competencies of taking up key roles in the institution. This sums up the effort of the university to invest in the development of employees, assess its progress toward the intended outcome which epitomises Drucker (2002) in his observation. However, some of the workers interviewed maintained that the Job Rotation program is sometimes used as a punitive tool on some of the supposedly 'stubborn' workers. One of the workers is quoted below;

"...sometimes you are posted to a department that does not relate to your profession just to frustrate you..."

\section{Criteria for selecting successors in UEW-K}

Figure 1.3 suggests that the main criteria adopted for selecting successors in UEW-K according to senior members and senior staff surveyed was 'Vetting' and eventually 'Interviewing' the potential successors. This finding was evidenced by the fact that 12 out of 20 respondents stated the use of vetting and interview as criteria for selecting potential candidates to occupy key positions. On that note, the performance of the likely successor will be assessed to ascertain the suitability of the candidate (figure 1.3).

\section{Personality traits as selection criteria for succession planning}




\section{International Journal of Social Sciences and Management Review}

As part of the criteria used in identifying successors to fill key roles in the University, the senior members and senior staff of the perceive that personality traits such as the successor's ability to work, level of intelligence, broadmindedness, straightforwardness and competencies of the potential successor are considered before appointing them to occupy key positions in the institution. However, it came to light that the senior members and senior staff have little consideration for the potential successor's desire to stay in the institution, inspirational qualities and fair-mindedness (Table 1.2).

In line with the position of Drucker (2002), senior members and senior staff surveyed asserted that education and training programmes as well as job rotational programmes have been designed to develop the competencies of employees to enable them to be successful when given higher positions in the (figure 1.4). The researcher's view regarding this finding is that education and training and job rotation have been the key succession planning program instituted and thus have been very beneficial to the course of succession planning activities in educational institutions. This is corroborated by the fact it is these two sets of practices that the employees surveyed profess to have benefitted from the most (Table 1.3). Again, Education and Training programmes came out on top as the practice mostly used to upgrade potential successor's capacity to take up higher-level positions in them as can be seen in table 1.6.

The discovery in table 1.7 , that most of the recruitment done in the was through internal recruitment sources as $56(70 \%$ of senior members and senior staff reported epitomizes the works of Harter, (2008) who found that $36 \%$ of HRDs considered it unnecessary for their organizations to be recruiting from external sources as against less than $10 \%$ of CEOs and CFOs. In the case of the current study, the researcher believes that there is minimal use of the external recruitment sources as less than $10(18 \%)$ of the senior members and senior staff surveyed maintained.

\section{Challenges of succession planning}

From table $1.8,43(83 \%)$ of the senior members and senior staff surveyed admitted to encountering challenges with the implementation of succession planning policies in the institution. Further enquiry from table 1.9 revealed that the major challenge the institution faced was the inability to adequately motivate and retain key employees as indicated by $38(21 \%)$ of the respondents. This finding typifies the work of Greer, Jackson, and Fiorito, (1989) who maintained that succession planning implementation is likely to suffer as a result of having a lot of disinterested workers in the organization as a result of lack of motivation. This affects the motivation of the employees to partake in any meaningful succession planning activity. Another challenge mentioned by the members was the lack of financial resources $28(15 \%)$. Any meaningful succession planning activity depends to a large extent on the availability of workers. Lack of financial resources to motivate and satisfy employees' opens the door for them to leave for better salaries and benefits offered in other institutions. Furthermore, it was found that $25(14 \%)$ of the members pointed to the size of the organization as a challenge confirms the finding of Harter, (2008). This is a challenge because of the fact that UEW-K is not a full-on it's own and has always relied on the main campus for strategic decisions. Human Resource issues within Kumasi would require authorisation from the main campus and sometimes this compounds the problem, somewhat a 


\section{International Journal of Social Sciences and Management Review}

centralized human resource administration. An interesting finding was less emphasis on the option of limited information about employees (see table 1.9). This, the researcher believes it is as a result of the fact that the university has adequate information about its employees. Through the interview, most of the respondents asserted that the Training and Development program comes without any financial backing. One respondent quoted below;

"...they tell us to go and further our studies without study leave with pay..."

This challenge according to most of the respondents through the interview suggested that most of the workers are unable to sponsor their own studies since they are only offered study leaves without pay for the duration of the studies.

\subsection{SUMMARY, CONCLUSION AND RECOMMENDATION}

\section{Existence of Succession Planning Policy at UEW - K}

There was a greater appreciation among the Junior Staff members of the fact that the University of Education has a succession planning policy in place to ensure the continual supply of competent personnel in pole position to occupy key roles in the organization. The university has therefore instituted programmes that ensure the continual development of the competencies of the employees. Training and Development and Job Rotational strategies have been implemented by the university to ensure the continual learning of the employees both on and off-the-job.

These strategies have come in the form of Education and Training practices and Job Rotation practices to upgrade potential successor's capacity to take up higher-level positions in the University. There has been less use of practices such as Executive Coaching, Mentoring and Job Shadowing. It was therefore unsurprising to discover from the respondents that Education and Training and Job Rotation practices adopted by them have been the practices that they have benefited from the most.

In relation to the benefits that accrue to the University, succession planning ensures that there is a continuous supply of qualified and motivated people who are prepared to take over when the current senior staff and other key employee abdicate the institution. Again, succession planning creates an alignment between the institution's vision and human resources that demonstrates an understanding of the need to have appropriate staffing to achieve strategic plans.

\section{The criterion for selecting Successors at UEW-K}

It was thus an established fact that the university has its special criteria for selecting potential successors. By way of the criteria, potential successors are taken through a process of vetting and interview to assess the suitability of the potential successors to fill the key roles. Not only is the candidate vetted and interviewed but also there is a performance assessment of the potential candidate as well. There is the whole scrutiny of the personality traits of the potential candidate. This is done to further check the suitability of the candidate to occupy an important role in the organization. The responses showed that selectors looked for candidates 


\section{International Journal of Social Sciences and Management Review}

who have the ability to work, hardworking, intelligent, broadminded, straightforward and above all competent enough to handle the responsibilities that accrue with the position. Majority of the recruitments are done through internal recruitment sources.

\section{Challenges with the use of the Succession Plan Policy in UEW-K}

The major challenge to the successful implementation of succession planning policy in the university has been that the university has been unable to adequately motivate and retain key employees in the institution. There is also the challenge of inadequate funding to support the succession planning programs for instance grant study leave with pay to enable the employees go for further studies.

Most importantly the policy implementation is challenged by the enormous bureaucratic structure ever-present with the institution due to the size of the institution. Since UEW-K is a satellite campus there is the need for approval from the main campus regarding certain important activities.

How succession planning policies can be implemented in UEW-K

It was found that the best way to successfully implement a succession plan policy in UEW-K is for the university to find the best way to motivate the employees with the intention of retaining their services for the foreseeable future of the organization.

\subsection{CONCLUSION}

The importance of succession planning in the day-to-day activities of UEW-K cannot be overemphasized. Indeed various levels within the structure of the institution appreciate the importance of putting measures in place to ensure that there is a perpetual supply of abled and competent workforce to draw from whenever the need arises to fill higher-level positions in the institution. This research has established that there exists a succession plan policy in place in the university which affords the institution the opportunity to prepare its employees to take up key roles in the institution. In view of that, the university is using a host of succession planning strategies to that effect. These include Training and Development and Job Rotation. There has been minimal use of Mentoring, Job Shadowing and Executive Coaching by the university. Again, the as part of the plan has criteria for selecting potential candidates for succession in the and this comes in the form of subjecting selected employees to a process of vetting and interview and then performance assessment regime. The personality traits of the candidates are scrutinized as well. The has adopted strategies through which it implements the policy which includes training and developing the workers through Education and Training practices and Job Rotation, to which the workers confess benefiting from. The effective implementation of the succession planning policy has not gone unchallenged. The policy is faced with inadequate funding to effectively carry out programs and practices in order to reap the benefits thereof. Finally, this research has maintained that for effective implementation of the succession plans at UEW-K the university has to find a way to adequately motivate and retain employees.

Implications for further research 


\section{International Journal of Social Sciences and Management Review}

This study has a few shortcomings or discussible issues, which may be taken into consideration when conducting similar studies in the future. First of all, the data collected was restricted to only a section of a bigger community. Again, the sample size used for the study was relatively smaller. Although there were clear distinctions concerning the demands of the purposes of the study, the results could be different if extended to all the four campuses of the university. It is therefore recommended that future research should concentrate on the following:

i. Designing an appropriate succession planning model for the University of Education, Winneba.

ii. How to use effective succession planning policy to address recruitment challenges facing the University.

\section{REFERENCES}

Alexander, M. (2005, January 17), Saving succession from politics and indifference. Canadian HR Reporter. 18(1), 8. Retrieved May 5, 2005 from ProQuest.

Blackaby, H., \& Blackaby, R. (2001). Spiritual leadership. TN: Broadman and Holman.

Brooks, K. and F.M. Nafukho, 2006. Human resource development, social capital, emotional Intelligence: Any link to productivity? J. Eur. Ind.

Butterfield, B. (2008). Talent Management: Emphasis on Action. CUPAHR Journal, 59 (1): 34-38.

Charan, R., Drotter, S., \& Noel, J. 2001. The Leadership Pipeline - How to Build the Leadership-Powered Company. San Francisco, CA: Jossey-Bass.

Following the leaders. (2005, April 7). Marketing Week. p. 24. Retrieved May 5, 2005 from ProQuest.

French, W. L., \& Bell, C. H. (1999). Organization Development (6th ed.). Englewood Cliffs, NJ: Prentice Hall.

French, W., \& Bell, C. (1999). Organization development: Behavioural science interventions for organization improvement. Upper Saddle River, NJ: Prentice-Hall.

Hammond, S. A. (1998). Thin Book of Appreciative Inquiry (2nd edition).

Thin Book Publishing Co.

Garman, A.N. \& Glawe, J. (2004). Succession planning. Consulting Psychology Journal: Practice and Research, 56(2), 119-128.

George, B. (2003). Authentic leadership. CA: Jossey-Bass. 


\section{International Journal of Social Sciences and Management Review}

Greer, C.R., Jackson, D.L., \& Fiorito, J. (1989). Adapting Human Resource Planning in a Changing Business Environment. Human Resource Management, 28(1): 105123.

Gross, B. (1968). Organizations and Their Managing. New York: The Free Press, 454.

Harter, L. (2008). Succession Planning Part II: Business Succession is a Team Sport. Journal of Practical Estate Planning, October-November, 2008.

Hazarika, A. (2009). Building the Pipeline: Leadership Succession is a Key Challenge. Leadership in Action. 29 (4):8-12.

Jepson, E J Jr. (2004a). The adoption of sustainable development policies and techniques in U.S. cities: How wide, how deep, and what role for planners? Journal of Planning Education and Research 23(3), 229-241.

Jepson, E J Jr. (2004b) Human nature and sustainable development: a strategic challenge for planners. Journal of Planning Literature 19(1), 3-15.

Jusko, J. (2005). Unplanned future. Industry Week. 254(3), 20. Retrieved May 5, 2005 from ProQuest.

Marshall, J. (2007). How to Succeed at Succession. Financial Executive, 23(8), 37-40.

Mercer, S. R. (2005, March). Best-in-class leadership. Leadership Excellence. 22(3), 17. Retrieved May 5, 2005 from ProQuest.

Orellano, V. I. F. (1997). A study of the determinants of turnover of hand work in the metropolitan region of Sao Paulo. Master's thesis, IPE-USP, Sao Paulo.

Pfeffer, J. (1998). The human equation. Massachusetts: Harvard Business School Press.

Robbins, S. (2003), Organizational Behaviour (10th, Ed.). Patparganj, Delhi, India: Pearson Education (Singapore) Pte. Ltd.

Rothwell,W. (2001). Effective succession planning. New York: American Management Association.

Scharmer, C.O. (2007). Theory U: Leading the Future as it Emerges. Cambridge, MA: The Society for Organizational Learning, Inc.

Schramm, J. (2005) Learning curves. HR Magazine. 50(2), 144. Retrieved May 5, 2005 from ProQuest.

Singer, P., Goodrich, J., Goldberg, L., (2004). Your Library's Future: when Leaders leave, Succession Planning can smooth transitions. Libr Journal. 129 (17):38-40. 


\section{International Journal of Social Sciences and Management Review}

Sparrow, P. (1992). Human resource planning at Engindorf plc. In: Winstanley, D., Woodall, J. (eds). Case Studies in Personnel. IPD; pp. 252-259.

Tichy, N. M.,; Devanna, M. A. (1990). The transformational leader. New York: John Wiley and Sons.

Wharton, C. R. Jr. (2005, February 15). Personal reflections on leadership. Vital Speeches of the Day. 71(9), 270. Retrieved May 5, 2005 from ProQuest. 